\title{
Impact of Altitude on Population Structure and Regeneration Status of Two Rhododendron Species in a Temperate Broad Leaved Forest of Arunachal Pradesh, India
}

\author{
Sanjeeb Bharali ${ }^{1, *}$, Ashish Paul ${ }^{1}$, Mahamed Latif Khan ${ }^{1,2}$, Lal Bihari Singha ${ }^{1}$ \\ ${ }^{1}$ Department of Forestry, North Eastern Regional Institute of Science and Technology (Deemed University), Nirjuli, Arunachal Pradesh, \\ 791109, India \\ ${ }^{2}$ Department of Botany, Guru Ghasidas University, Koni, Bilaspur, Chhattisgarh, 495009, India
}

\begin{abstract}
An attempt had been made to study the impact of altitude on population structure and regeneration status of two Rhododendron species as well as its associated species in a temperate forest of Arunachal Pradesh. Population structure was worked out based on the density of seedlings, saplings and adults while, the regeneration status was determined from the population size of seedlings, saplings and adults. The mid altitude site (Hanuman Camp) has highest density (2692 individuals $\mathrm{ha}^{-1}$ ) comprising of seedlings, saplings and adults of all species followed by lower altitude (Shagong) site (2379 individuals $\mathrm{ha}^{-1}$ ) and lowest at (Yarlung) higher altitude site $\left(2180\right.$ individuals $\left.\mathrm{ha}^{-1}\right)$. However, the relative proportion of seedlings of all woody species was recorded highest in low altitude site, while it was lowest in higher altitude. Conversely, the relative proportion of saplings and adults were highest in higher altitude. The selected Rhododendron species shows reverse $\mathrm{J}$ shaped population structure and fair regeneration status in all study stands having higher number of seedlings compared to saplings. However, the number of saplings is less than the adults. It was observed that the seedling populations dominate the overall population of the selected Rhododendron species. Moreover, it was found that although altitude does not affect regeneration status, but affects the population structure of the selected Rhododendrons. The fluctuation in population density of seedlings, saplings and adults along the altitudinal gradient may be linked with the prevailing environmental factors.
\end{abstract}

Keywords Population Size, Biotic and Abiotic factors, Canopy, growth

\section{Introduction}

Population is a basic community component i.e., the population structure has a direct impact on the community structure, which in turn demonstrates the development trend of the community[1,2]. The population structure of a tree species reflects its biological and ecological characteristics [3] and it refers to the distribution of individuals in different height classes to provide the regeneration profile. Although diameter/girth at breast height $(\mathrm{DBH} / \mathrm{GBH})$ is the most commonly used size variable in the analysis of population structure, height class distribution for seedlings and saplings have also been used for the study of population structure of tree species[4-6]. The inclusion of seedlings and saplings in plant population structures would provide better information about the status of the species at early stage of

* Corresponding author:

sanjeebbharali@yahoo.co.in (Sanjeeb Bharali)

Published online at http://journal.sapub.org/ije

Copyright (C) 2012 Scientific \& Academic Publishing. All Rights Reserved regeneration. Plants maintain and expand their populations in time and space by the process of regeneration. Population dynamics of plant species can be described by demographic variables such as the recruitment, mortality and growth rates of individuals[7] and the balance among these variables has been found to regulate the dynamics and the structure of a population[8]. Regeneration of any species is restricted to a peculiar range of habitat conditions and the extent of those conditions is a major determinant of its geographic distribution[9]. However, natural regeneration of a tree species largely depends on production and germination of seeds, establishment of seedlings and saplings[10].

The pattern of population dynamics of seedlings, saplings and adults of a plants species can exhibits the regeneration profile, which is used to determine their regeneration status[11,12]. A population with sufficient number of seedlings and saplings depicts satisfactory regeneration behaviour, while inadequate number of seedlings and saplings of the species in a forest indicates poor regeneration[13,14]. The density of seedlings and saplings are considered as regeneration potential of a species. Good and Good[15] con- 
sidered three major components for successful regeneration of a species viz., ability to initiate new seedlings, ability of seedlings and saplings to survive and ability of seedlings and saplings to grow. Moreover, plants could generally grow and survive in a limited range of environmental gradients, e.g. temperature and light availability[16] and variation in these factors play important roles in shaping the age structure and forest regeneration at different altitudes[17]. The population structure is the integrated exhibition of the status, function, development process and trends of tree species[2]. Thus, the regeneration type, dynamic process and trends of the community can be confirmed or speculated according to the characteristics of population structure[3]. Population structure studies along altitudinal gradients of a mountain would be helpful in understanding the influences of environmental factors on the regeneration of natural forests[18].

Arunachal Pradesh, by virtue of its geographical position, climatic conditions and altitudinal variations, is a biodiversity rich region in northeast India. Rhododendrons form the dominating species all along the cool temperate, subalpine and alpine zones in Arunachal Himalaya. About $85 \%$ of the Indian Rhododendron species are found in Arunachal Himalaya[19]. The rhododendrons in Arunachal Pradesh are also experiencing the impact of disturbance, which is resulted due to the shrinkage of green cover. This phenomenon is clearly visible in the temperate and sub alpine zones of Arunachal Himalaya, where ecosystem and the land physiography are supposed to be fragile and easily disturbed. The major threats to rhododendrons are large-scale deforestation of their suitable habitats and unsustainable extraction for firewood by local people[19]. Moreover, till date no detailed studies on population structure and regeneration status of Rhododendron species with reference to altitude particularly in Arunachal Himalaya have been carried out. Keeping this in view, an attempt had been made to assess the impact of altitude on population structure and regeneration status of two selected Rhododendron species (viz., Rhododendron kenderickii and Rhododendron grande) as well as its associated species in West Siang district of Arunachal Pradesh. $R$. kenderickii is reported as rare in Arunachal Himalaya[19,20] while, $R$. grande is threatened in Sikkim Himalaya[21].

\section{Materials and methods}

\subsection{Study site}

Arunachal Pradesh, the largest state in northeastern region of India forms a major part of Eastern Himalaya and is predominantly hilly and mountainous[22]. The state is also recognized as one among the 200 globally important ecoregions[23]. The Rhododendron forest under the present study was located in Mechuka valley in West Siang district of Arunachal Pradesh, northeast India (Figure 1). The West Siang district lies between $27^{\circ} 32^{\prime}$ to $28^{\circ} 59^{\prime} \mathrm{N}$ latitude and $93^{\circ} 58^{\prime}$ to $94^{\circ} 58^{\prime} \mathrm{E}$ longitude. The district is spread over 7,813 sq. $\mathrm{km}$ and constitutes $9.33 \%$ of the total geographi- cal area of the state. The total forest cover of the district is 6,719 sq. $\mathrm{km}$ ( $86 \%$ of the total geographical area), out of which very dense forest comprises of $2,478 \mathrm{sq} . \mathrm{km}$, moderately dense forest $2,741 \mathrm{sq}$. $\mathrm{km}$ and open forest covers about 1,501 sq. km[24]. Mechuka falls under the Himalayan range and is characterised by rough topography with mountains, deeply incised valleys, escarpments and plateaus. Mechuka is bordered by Upper Siang district in the northeast, Upper Subansiri district in southwest, whereas the northwestern side is bordered by China. Climate of Mechuka can be characterized into four distinct seasons viz. winter with temperature below freezing point when maximum snowfall occurs, spring with little rainfall, rainy with highest rainfall and autumn with little shower. The precise age of the forest of the study area is not known due to non-availability of the forest history with the local forest department. Thick spongy humus layer covers the forest floor. The dominant species of the study area is Rhododendron kenderickii, R. grande, Abies densa, Taxus wallichiana, Pinus wallichiana etc. The forest is in climax stage and very old aged. The soil is coarse textured with sandy to loamy in nature and the $\mathrm{pH}$ ranged from $4.08-4.71$. The organic carbon content ranged from $4.87 \%-6.89 \%$ while, the total nitrogen, available phosphorus and exchangeable potassium content ranged from $0.15 \%-0.25 \%, 0.007 \%-$ $0.01 \%$ and $0.37 \%-0.43 \%$ respectively. The rock types in Mechuka can be categorised into two distinct groups namely Meta-sedimentaries and Gneisses[25].

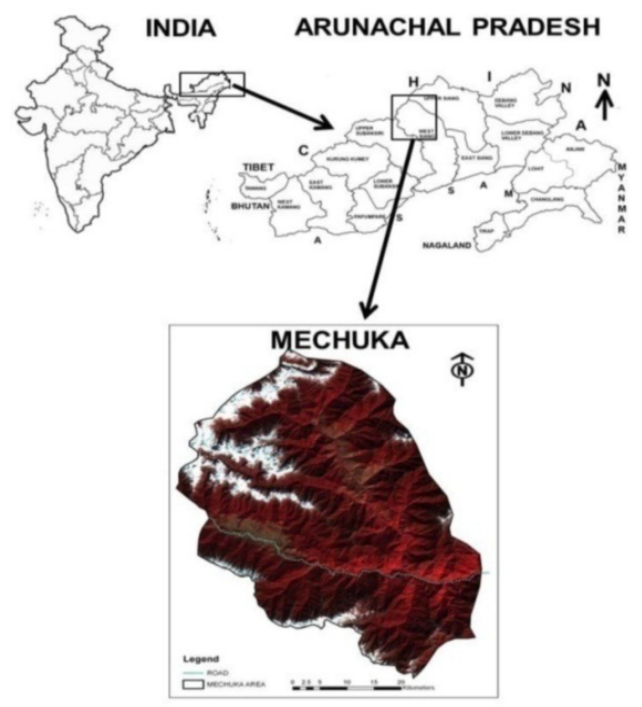

Figure 1. Map showing the study site

The forests of the study site exposed to various kinds of disturbances such as fuel wood collection, logging, clear felling, extraction of timber, fodder and other non-timber forest products by the local people. On the contrary, the area is shared with the international border to China and consequently the forests are recently being affected by the process of road construction and bunker preparation. For the present study the Rhododendron forest of the study site was divided 
into three study stands at different altitudinal zones viz, lower study stand (1900-2100m) at Shagong, middle study stand $(2100-2300 \mathrm{~m})$ at Hanuman camp and the upper study stand $(>2300 \mathrm{~m})$ at Yarlung.

\subsection{Methods}

\subsubsection{Population Structure}

Population structure of all the woody species occurring in each study stands along the altitudinal gradient was studied using quadrat method. Forty quadrats of $10 \mathrm{~m}$ x $10 \mathrm{~m}$ were laid randomly in each stand. The seedlings were also recorded within the same $10 \mathrm{~m} \times 10 \mathrm{~m}$ quadrats as they are sparsely distributed. Species were identified and densities of seedlings $(\leq 50 \mathrm{~cm}$ in height), saplings $(\leq 10 \mathrm{~cm}$ collar circumference at the base and $>50 \mathrm{~cm}$ height) and adults $(\geq 10$ $\mathrm{cm}$ girth at breast height, i.e. $1.37 \mathrm{~m}$ above ground level) were determined. Specimens of all species were collected and herbariums were prepared following Jain and Rao[26] and identification was done following flora references like Materials for the flora of Arunachal Pradesh, Flowers of Himalaya and Flora of Assam etc. The relative proportion of the seedlings, saplings and adults to total density of tree species in each study stand was calculated.

\subsubsection{Regeneration Status}

Regeneration status of species was determined based on population size of seedlings and saplings[27]: good regeneration, if seedlings > saplings > adults; fair regeneration, if seedlings $>$ or $\leq$ saplings $\leq$ adults; poor regeneration, if the species survives only in sapling stage, but no seedlings (saplings may be $<,>$ or $=$ adults).

\section{Results}

\subsection{Tree Species Composition}

The number of tree species encountered from the study sites varied from stand to stand. Highest number of tree species (21) was recorded from Hanuman Camp, followed by Yarlung (19) and least number from Shagong (15). Hanuman Camp has highest density (2692 individuals ha ${ }^{-1}$ ) of total seedlings, saplings and adults followed by Shagong (2379 individuals $\left.\mathrm{ha}^{-1}\right)$ and lowest at Yarlung (2180 individuals ha ${ }^{-1}$ ) (Table 1).

\subsection{Population Structure}

The population structure of tree species in terms of the proportion of seedlings, saplings and adults varied greatly in the three study stands (Figure 2). The relative proportion of seedlings was recorded highest in Shagong, while, it was lowest in Yarlung. On the other hand, the relative proportion of saplings and adults were highest in Yarlung followed by Hanuman Camp. The distribution of seedlings, saplings and adults along the altitudinal gradient also showed variations among species (Table 2).
Table 1. Floristic composition and density of individuals $\left(\mathrm{ha}^{-1}\right)$ in the three study stands

\begin{tabular}{|c|c|c|c|}
\hline \multirow{2}{*}{ Name of species } & \multicolumn{3}{|c|}{$\begin{array}{c}\text { Density }\left(\mathrm{ha}^{-1}\right) \\
\text { (Seedling }+ \text { Sapling }+ \text { Adult })\end{array}$} \\
\hline & Shagong & $\begin{array}{l}\text { Hanuman } \\
\text { Camp }\end{array}$ & Yarlung \\
\hline Abies densa Griff. & 62 & 15 & 16 \\
\hline Acer caesium Wall. ex Brandis & - & 164 & - \\
\hline Alnus nepalensis D.Don. & 113 & - & - \\
\hline Castanopsis armata Roxb. & - & - & 26 \\
\hline $\begin{array}{c}\text { Castanopsis tribuloides (Smith) } \\
\text { A. DC. }\end{array}$ & 129 & 150 & - \\
\hline Castanopsis indica Roxb. & 27 & 50 & - \\
\hline $\begin{array}{c}\text { Cinnamoтum glaucescens } \\
\text { Nees. }\end{array}$ & - & - & 53 \\
\hline Cornus capitata Wallich & - & 30 & - \\
\hline Eurya accuminata DC. & - & - & 22 \\
\hline Eurya sp. & 83 & 139 & - \\
\hline Grewia $\mathrm{sp}$ & - & - & 23 \\
\hline $\begin{array}{l}\text { Illicium griffithii Hook.f. \& } \\
\text { Thomson }\end{array}$ & 430 & 439 & 445 \\
\hline Leea sp. & 33 & 22 & 27 \\
\hline Litsea sericea (Nees) Hook. f. & 184 & 136 & 166 \\
\hline $\begin{array}{l}\text { Litsea glutinosa (Lour.) Rob- } \\
\text { inson }\end{array}$ & - & 38 & 109 \\
\hline Litsea $\mathrm{sp}$ & - & - & 105 \\
\hline Lyonia ovalifolia (Wall.) Drude & 99 & - & - \\
\hline $\begin{array}{c}\text { Magnolia hodgsonii Hook.f. \& } \\
\text { Thomson }\end{array}$ & 98 & 47 & 40 \\
\hline Persea sp. & - & 13 & - \\
\hline Pinus wallichiana A.B. Jacks. & 139 & - & 18 \\
\hline Prunus cerasoides D.Don. & - & 27 & - \\
\hline Quercus lamellosa Sm. & 163 & - & 7 \\
\hline $\begin{array}{c}\text { Rhododendron arizelum I. B. } \\
\text { Balfour \& Forrest }\end{array}$ & - & 124 & 154 \\
\hline Rhododendron grande Wight & 342 & 576 & 283 \\
\hline Rhododendron kenderickii Nutt. & 447 & 420 & 296 \\
\hline Rhododendron sp. & - & 216 & 334 \\
\hline Taxus wallichiana Zuccarni. & 30 & 33 & 43 \\
\hline Tsuga sp. & 62 & 13 & - \\
\hline Unidentified 1 & - & 23 & - \\
\hline Unidentified 2 & 113 & 17 & 13 \\
\hline Total & 2379 & 2692 & 2180 \\
\hline
\end{tabular}

The selected Rhododendron tree species shows good population structure in all the study stands with seedlings, saplings and adults. However, there is a variation in density $\left(\mathrm{ha}^{-1}\right)$ of seedlings, saplings and adults in the three study stands. R. kenderickii exhibits gradual decrease in density $\left(\mathrm{ha}^{-1}\right)$ of seedlings and adults from Shagong to Yarlung while, density $\left(\mathrm{ha}^{-1}\right)$ of sapling was highest in Hanuman Camp. On the other hand, $R$. grande has highest density $\left(\mathrm{ha}^{-1}\right)$ of seedlings, saplings and adults in Hanuman Camp followed by Shagong and Yarlung. However, sapling density $\left(\mathrm{ha}^{-1}\right)$ is more in Yarlung compared to Shagong (Figure 3). Inspite of this variation in density of seedlings, saplings and adults, a reverse $\mathrm{J}$ shaped population structure was shown by both the selected Rhododendron species in the three respective study stands (Figure 4).

Table 3 shows the density $\left(\mathrm{ha}^{-1}\right)$ and basal area $\left(\mathrm{m}^{2} \mathrm{ha}^{-1}\right)$ of the selected Rhododendron species in the three study stands. $R$. kenderickii is the main dominant species in Shagong, while, it occurs as a co-dominant species in Yarlung. $R$. grande dominates the study stand at Hanuman Camp. 
Moreover, it was found that among the three study stands $R$. kenderickii has highest density in Shagong while, lowest in Yarlung. Similarly $R$. grande has highest density in Hanuman Camp while, lowest in Yarlung.

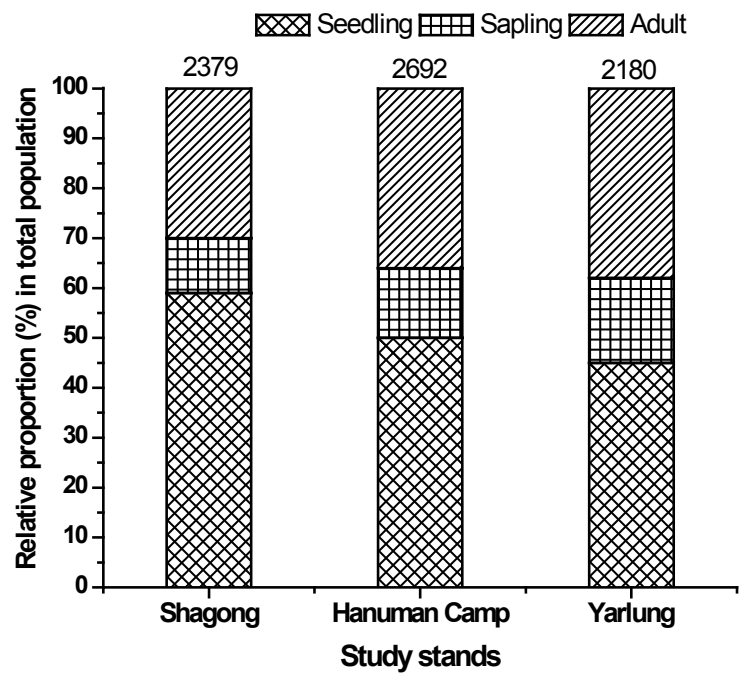

Figure 2. Population structure of tree species in the three study stands

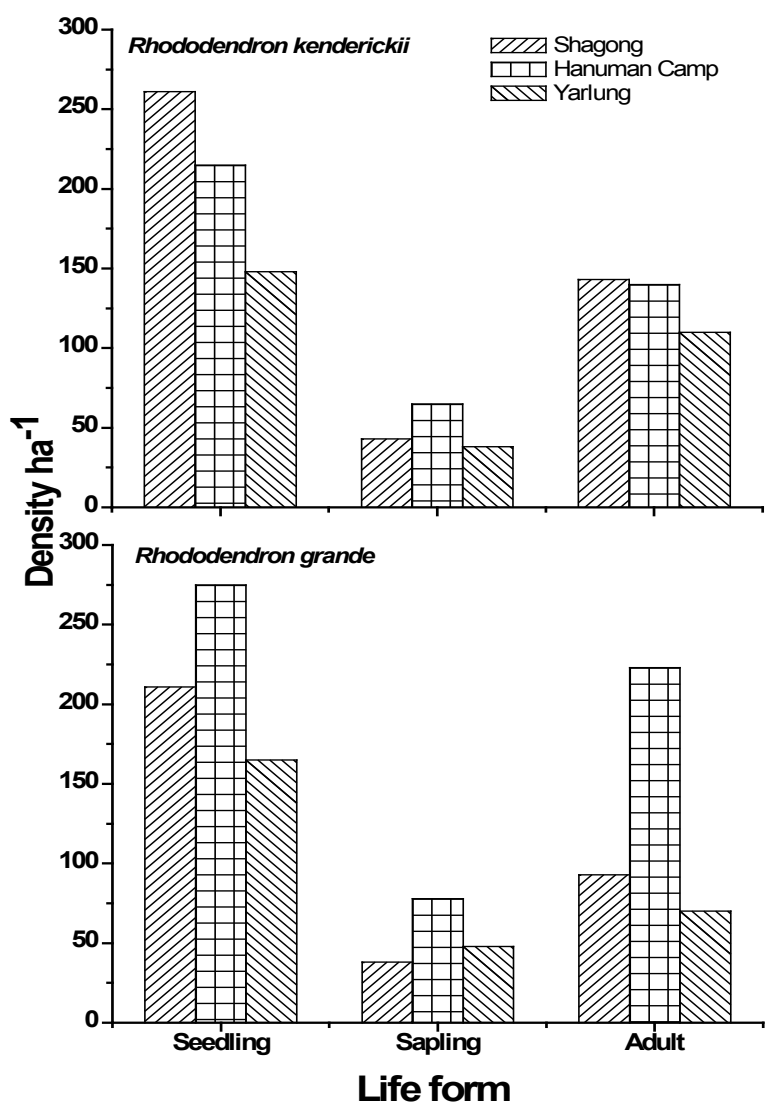

Figure 3. Variation in density $\left(\mathrm{ha}^{-1}\right)$ of seedlings, saplings and trees of the selected Rhododendron species in the three study stands

\subsection{Regeneration status}

Out of the 15 tree species recorded from Shagong, 67\% shows fair regeneration and $6 \%$ have good regeneration, $7 \%$ poor regeneration while, remaining exhibits no regeneration.
In Hanuman Camp out of the 21 tree species recorded, 5\% exhibits good regeneration, $38 \%$ fair regeneration, $26 \%$ poor regeneration and $27 \%$ no regeneration. On the other hand, out of the 19 tree species recorded in Yarlung, 5\% shows good regeneration, $42 \%$ fair regeneration, $26 \%$ poor and $27 \%$ exhibits no regeneration (Figure 5).

The selected Rhododendron species (viz., Rhododendron kenderickii and $R$. grande) shows fair regeneration in all the study stands having higher number of seedlings compared to saplings. However, the number of saplings is less than the adults (Table 2).

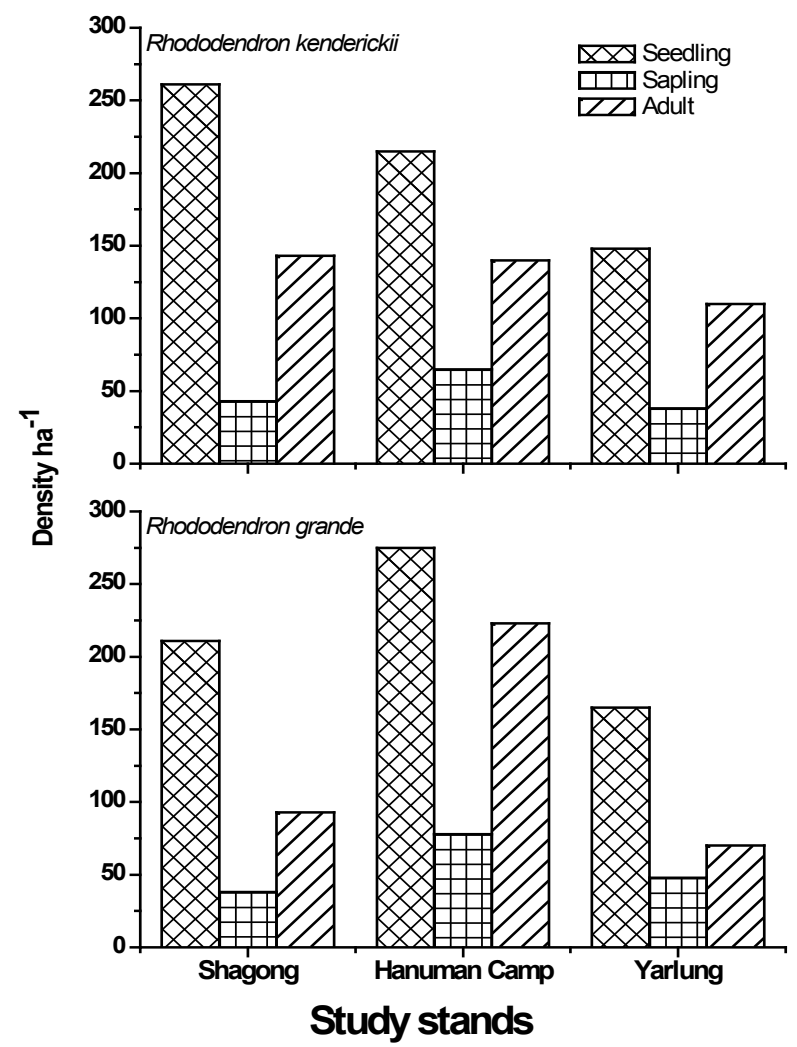

Figure 4. Population structure of the selected Rhododendron species at the three study stands

\section{Discussion}

The future community structure and regeneration status of the plant species could be predicted from the relative proportion of seedlings, saplings and adults in the total populations of various species in the forest. The overall population structure of tree species in the three study stands showed that contribution of seedlings was highest to the total population followed by adults and saplings. Variation in proportion of seedlings, saplings and adults were observed in all study stands. This differences in relative proportion of seedlings, saplings and adults among the three study stands may be due to the interactive influence of an array of biotic and abiotic factors[28]. According to Jones et al.[29], seedling layer in various forests differs in composition from their respective over storey. 
The variation among the population size of seedlings, saplings and adults at the three study stands may be due to the variation in climatic as well as edaphic factors required by the selected Rhododendron species for growth and survival. Tasfeye et al.[30] also reported similar variation in seedling density among species along altitudinal gradient in dry Afromontane forest, Southern Ethopia. Inspite of variation in density the selected Rhododendron species (viz., $R$. kenderickii and $R$. grande) exhibit reverse J shaped distribution in all the study stands. Paul[31] also reported similar type of distribution from temperate broad-leaved forest of rhododendrons ( $R$. arboreum, $R$. arboreum ssp. delavayi var. delavayi, $R$. barbatum and $R$. kesangiae). Moreover, Miyadokoro et al.[32] from subalpine old-growth coniferous forest, central Japan reported reverse J shaped distribution. Shrestha[33] has also reported that population of Betula utilis both in mixed and pure forests nearly resembled a reverse J-shaped in forest trans-Himalayan dry valley in Manang (central Nepal). Wangda and Ohsawa[34] have reported that three types of population structure i.e. unimodal, sporadic and reverse-J shaped by the dominant species along the altitudinal gradient in dry valley slopes of the Bhutan Himalaya. Duan et al.[17] studied the population structure of Larix chinenesis in Qinling Mountains (China) and reported that population structure in the low altitude transect was closed to bell-shaped and characterized by the dominance of adult trees while, a reverse-J shape age structure was found in the mid-altitude transect. Multi-modal age distribution was found in the high altitude transect, and was caused by lack of young seedlings and saplings. Yang[35] have also reported that the main populations of Badaling forest in Beijing, China can be divided into 4 types of population structures: sporadic type (Quercus mongolica), reverse J type (Tilia mandshurica and T. mongolica), unibar type (Fraxinus rhynchophylla) and ladder type (Betula dahurica and Acer mono). Moreover, Zegeye et al.[36] studied the population structure of woody species in Tara Gedam and Abebaye forests, northwestern Ethiopia and reported that all the woody species shows a reverse $\mathrm{J}$ type population structure. Reverse " $\mathrm{J}$ " distribution is considered as an indication of stable population structure with fairly good regeneration status[37-39]. Further, it was also reported that the seedling pool of Rhododendron simiarum were abundant and the age structure was stable and population can stably expand in the community. It might be determined by its biological characteristics and the integrated environmental influence[40]. The population structure variations among the selected Rhododendron species in three study stands might be ascribed to the differences in their habitats and existing micro environmental factors[41].

Table 2. Distribution of seedlings, saplings and adults (density ha $\left.{ }^{-1}\right)$ and regeneration status of different tree species in the three study stands

\begin{tabular}{|c|c|c|c|c|c|c|c|c|c|c|c|c|}
\hline & \multicolumn{3}{|c|}{ Shagong } & \multirow{2}{*}{ Status } & \multicolumn{3}{|c|}{ Hanuman Camp } & \multirow{2}{*}{ Status } & \multicolumn{3}{|c|}{ Yarlung } & \multirow{2}{*}{ Status } \\
\hline & SE & SA & $\mathrm{AD}$ & & $\mathrm{SE}$ & SA & $\mathrm{AD}$ & & $\mathrm{SE}$ & SA & $\mathrm{AD}$ & \\
\hline Abies densa & 45 & - & 17 & FR & - & 5 & 10 & PR & - & 3 & 13 & $\mathrm{PR}$ \\
\hline Acer caesium & - & - & - & - & 124 & 10 & 30 & FR & - & - & - & - \\
\hline Alnus nepalensis & 61 & 25 & 27 & FR & - & - & - & - & - & - & - & - \\
\hline Castanopsis armata & - & - & - & - & - & - & - & - & - & 3 & 23 & PR \\
\hline Castanopsis tribuloides & 79 & 13 & 37 & FR & 77 & 20 & 53 & FR & - & - & - & - \\
\hline Castanopsis indica & - & - & 27 & NR & & 3 & 47 & PR & - & - & - & - \\
\hline Cinnamomum glaucescens & - & - & - & - & - & - & - & & 10 & 13 & 30 & FR \\
\hline Cornus capitata & - & - & - & - & - & - & 30 & NR & - & - & - & - \\
\hline Eurya accuminata & - & - & - & - & - & - & - & & - & 5 & 17 & PR \\
\hline Eurya sp. & 46 & 10 & 27 & FR & 96 & 13 & 30 & FR & - & - & - & - \\
\hline Grewia sp & - & - & - & - & - & - & - & - & - & - & 23 & NR \\
\hline Illicium griffithii & 279 & 81 & 70 & GR & 268 & 91 & 80 & GR & 245 & 110 & 90 & GR \\
\hline Leea $\mathrm{sp}$ & - & 3 & 30 & PR & - & 5 & 17 & PR & - & - & 27 & NR \\
\hline Litsea sericea & 98 & 13 & 73 & FR & 76 & 20 & 40 & FR & 90 & 33 & 43 & FR \\
\hline Litsea glutinosa & - & - & - & - & - & 5 & 33 & PR & 47 & 15 & 47 & FR \\
\hline Litsea $\mathrm{sp}$ & - & - & - & - & - & - & - & - & 62 & 13 & 30 & FR \\
\hline Lyonia ovalifolia & 61 & 8 & 30 & FR & - & - & - & - & - & - & - & - \\
\hline Magnolia hodgsonii & 45 & 3 & 50 & FR & - & - & 47 & NR & - & - & 40 & NR \\
\hline Persea sp. & - & - & - & & - & 3 & 10 & PR & - & - & - & \\
\hline Pinus wallichiana & 104 & 15 & 20 & FR & - & - & - & - & & 5 & 13 & PR \\
\hline Prunus cerasoides & - & - & - & - & - & - & 27 & NR & - & - & - & - \\
\hline Quercus lamellosa & 112 & 18 & 33 & FR & - & - & - & - & - & - & 7 & NR \\
\hline Rhododendron arizelum & - & - & - & - & 91 & 13 & 20 & FR & 66 & 28 & 60 & FR \\
\hline Rhododendron grande & 211 & 38 & 93 & FR & 275 & 78 & 223 & FR & 165 & 48 & 70 & FR \\
\hline Rhododendron kenderickii & 261 & 43 & 143 & FR & 215 & 65 & 140 & FR & 148 & 38 & 110 & FR \\
\hline Rhododendron sp. & - & - & - & - & 128 & 38 & 50 & FR & 152 & 55 & 127 & FR \\
\hline Taxus wallichiana & - & - & 30 & NR & - & - & 33 & NR & - & 3 & 40 & PR \\
\hline Tsuga sp. & - & - & - & - & - & - & 13 & NR & - & - & - & - \\
\hline Unidentified 1 & - & - & - & - & - & 10 & 13 & PR & - & - & - & - \\
\hline Unidentified 2 & - & - & - & - & - & - & 17 & NR & - & - & 13 & NR \\
\hline
\end{tabular}


Table 3. Density of individuals $\left(\mathrm{ha}^{-1}\right)$ and basal area $\left(\mathrm{m}^{2} \mathrm{ha}^{-1}\right)$ of selected Rhododendron tree species in the three study stands

\begin{tabular}{cccc}
\hline $\begin{array}{c}\text { Study } \\
\text { stands }\end{array}$ & Name of Species & $\begin{array}{c}\text { Density } \\
\left(\mathrm{ha}^{-1}\right)\end{array}$ & $\begin{array}{c}\text { Basal Area } \\
\left(\mathrm{m}^{2} \mathrm{ha}^{-1}\right)\end{array}$ \\
\hline \multirow{2}{*}{ Shagong } & $\begin{array}{c}\text { Rhododendron kenderickii } \\
\text { Rhododendron grande }\end{array}$ & $\begin{array}{c}143 \\
93\end{array}$ & 3.18 \\
\hline Hanuman & $\begin{array}{c}\text { Rhododendron kenderickii } \\
\text { Camp }\end{array}$ & 140 & 6.65 \\
\hline \multirow{2}{*}{ Yarlung } & Rhododendron grande & 223 & 9.77 \\
& Rhododendron kranderickii & 110 & 3.4 \\
\hline
\end{tabular}

The overall regeneration status of the tree species in the study stands exhibit fair regeneration with density of sapling population less than seedlings and adults. The seedling and sapling densities in forest understories are not stable, rather it is dynamic in nature and this dynamism may vary among various species[42]. The change in density is due to mortality, which could include abiotic stresses such as light, drought and biotic factors that include herbivory, disease or competition[43]. Successful regeneration of any type of species can only occur if the right amount of growing space becomes available for the establishment and subsequent growth of seedlings[44]. Ericaceous understory plants in general and rhododendron species in particular were shown to compete with and in some cases, totally inhibit canopy tree regeneration in temperate forest ecosystems throughout the northern hemisphere[45-48]. Shagong have the highest number of species, which shows fair regeneration. This could be due to enough solar radiation, nutrients availability etc. which help the tree species in better regeneration. Pokhreyal et al.[49] also reported presence of tree species with higher proportion of fair regeneration from Phakot and Pathri Rao watersheds in Garhwal Himalaya. In contrast, Tiwari et al.[50] have reported tree species with $81.8 \%$ good regeneration status from Garhwal Himalaya. On the other hand, Chauhan et al.[51] studied the regeneration and tree diversity and reported that only $32.5 \%$ of the total 126 species shows good regeneration in natural and planted forest in Katarniaghat Wildlife Sanctuary. Zegeye et al.[35] also mention poor regeneration status of few species in temperate forest of north eastern Ethopia and emphasized on conservation priorities of those species. Moreover, the variation in seedling density among species along the altitudinal gradient may be due to change in climatic condition (low temperature, rainfall and high humidity) which would restrict the distribution of some species as well as germination and establishment of seedlings[52, 53].

The selected Rhododendron species in all the three study stands shows fair regeneration with higher number of seedlings followed by adults and saplings. Similar kind of findings i.e. fair regeneration of rhododendrons has been reported from temperate broad-leaved forest of Arunachal Pradesh[30]. The presence of high number of seedlings of the selected rhododendrons indicates that seedlings were the main mode of regeneration. During the study, it was observed that very few Rhododendron seedlings were found beneath the canopy, but they are abundant in open places like steep slopes, forest margins and bank of streams. This may be because of the reason that light is an absolute requirement for germination of Rhododendron seeds[54-57]. The presence of larger number of seedlings might be attributed to the establishment of microsites, which facilitates the germination of large number of Rhododendron seeds in open places.

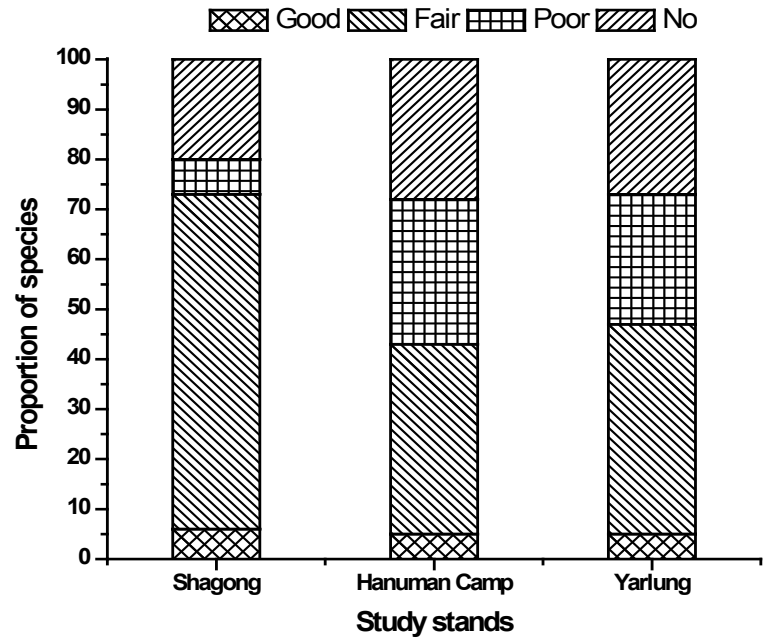

Figure 5. Regeneration status of tree species in the three study stands

The low sapling population of the selected species in the three respective study stands in spite of the presence of high number of seedlings as well as adults may be attributed to the adverse impact of environmental factors prevalent during the sapling growth resulting into large-scale death of saplings and small trees before they reach to the canopy. Similar observation was reported by Shrestha[58] for Quercus semecarpifolia in the Himalayan region. Moreover, close canopy and insufficient light intensity along with thick litter layer[59] at the ground surface may reduce the establishment capacity of Rhododendron seedlings and saplings. Kameyama et al.[60] reported that growth and survival of seedlings of Rhododendron metternichii Sieb. et Zucc. var. hondoense Nakai were highly dependent on the ground conditions and the canopy cover in Mt. Kamakuraji of Hiroshima Prefecture, Japan. Moreover, in a mature forest with closed canopy, seedling establishment is constrained by lower light intensity on the ground surface. Thus, they were well represented at the adult stage but not by sapling stage, as seedlings require light environment[61,62]. Koirala[63] reported that the closed canopy in a climax Rhododendron forest might be the reason for low seedlings and saplings density of Rhododendron species.

\section{Conclusions}

It can be concluded that, seedling populations in all the three study stands dominate the overall population of the selected Rhododendron species. Moreover, it was found that although altitude does not affect regeneration status of the selected Rhododendron species, but affects the population structure. The fluctuation in population density of seedlings, saplings and adults along the altitudinal gradient may be 
linked with the prevailing environmental factors. The selected Rhododendron species have fair regeneration status in all study stands as indicated by low population size of saplings compared to seedlings and adult, which may be due to close canopy as well as absence of other favorable environmental factors such as light, temperature, moisture, nutrients etc. for growth and survival.

\section{ACKNOWLEDGEMENTS}

We thank the PCCF, Arunachal Pradesh and Additional Deputy Commissioner, Mechuka for research permit. The corresponding author thankfully acknowledges the financial support provided by University Grant Commission, GOI, through Rajiv Gandhi National Fellowship.

\section{REFERENCES}

[1] Xia, A.M., Da, J.L., Zhu, H.X. and Zhao, M.S., 2004, Community structure and regeneration pattern of Cryptomeria fortunei in Mount Tianmu of Zhejiang, China, Journal of Zhejiang University, 21(1), 44-50

[2] Zhang, Y., Zheng, Zhi-hua, and Zhang, Zhi-xiang, 2007, Community structure and regeneration types of Betula dahurica forest in Badaling forest center of Beijing, Forestry Studies in China, 9(2), 152-156

[3] Da, L.J., Yang, Y.C. and Song, Y.C., 2004, Population structure and regeneration types of dominant species in an evergreen broadleaved forest in Tiantong National forest Park, Zhejiang province, Eastern China, Chinese Journal of Plant Ecology, 28(3), 376-384

[4] Geldenhuys, C.J., 1993, Reproductive biology and population structure of Podocarpus falcatus and P. latifolias in southern Cape forest, Botanical Journal of the Linnean Society, 112(1), 59-74

[5] Breckle, S.W., 1997, Population studies on dominent and abundent tree species in the montane tropical rain forests of the biological reserve North of San Ramon, Costa Rica, Tropical Ecology, 38(2), 259-272

[6] Damel, T., 1997, Seedling populations and regeneration of woody species in dry Afromantane forest of Ethopia, Forest Ecology and Management, 98(2), 149-165

[7] Watkinson, A.R., 1997, Plant population dynamics, Crawly M.J. eds, Plant Ecology. 2nd Edn. Blackwell, Oxford

[8] Kohyama, T. and Hara, T., 1989, Frequency distribution of tree growth rate in natural forest stands, Annals of Botany, 64(1), 47-57

[9] Grubb, P.J., 1977, The maintenance of species-richness in plant communities: the importance of the regeneration niche, Biological Review, 52(1), 107-145

[10] Rao, P.B., 1988, Effects of environmental factors on germination and seedling growth in Querscus floribunda and $\mathrm{Cu}$ pressus torulosa, tree species of central Himalaya, Annals of Botany 61(4): 531-540
[11] Bekele, T., 1994, "Studies on remnant Afromontane forests on the central plateau of Shewa, Ethiopia", Ph.D. thesis, Uppsala University, Uppsala

[12] Teketay, D., 1996, "Seed ecology and regeneration in dry Afromontane forests of Ethiopia", Ph.D. thesis, Swedish University of Agricultural Sciences, Umea

[13] Khan, M.L., Rai, J.P.N. and Tripathi R.S., 1987, Population structure of some tree species in disturbed and protected sub-tropical forests of north-east India, Acta Oecologica-Oecologia Applicata, 8(3), 247-255

[14] Tripathi, R.S. and Khan M.L., 2007, Regeneration Dynamics of Natural Forests - A Review, Proceedings of the Indian National Science Academy, 73(3), 167-195

[15] Good, N.F. and Good, R.E., 1972, Population dynamics of tree seedlings and saplings in mature Eastern hardwood forest, Bulletin of the Torrey Botanical Club 99(4): 172-178

[16] Block, J. and Treter, U., 2001, The limiting factors at the upper and lower forest limits in the mountain-woodland steppe of Northwest Mongolia Joachim Block and Uwe Treter, In, Kaennel, D.M. and Braker, O.U. eds, Proceedings of the International Conference on Tree Rings and People, Davos

[17] Duan, R.Y., Wang, X.A., Tu, Y.B., Huang, M.Y., Wang, C., Zhu, Z.H. and Guo, H., 2009, Recruitment pattern of tree populations along an altitudinal gradient: Larix chinensis in Qinling mountains (China), Polish Journal of Ecology, 57(3), 451-459

[18] Wang, T., Liang, Y.H., Ren, B., Yu, D., Ni, J., Ma, K.P., 2004, Age structure of Picea schrenkiana forest along an altitudinal gradient in the central Tianshan Mountains, northwestern China, Forest Ecology and Management, 196(2-3), 267-274

[19] Paul, A., Khan, M.L., Arunachalam, A. and Arunachalam, K., 2005, Biodiversity and conservation of Rhododendrons in Arunachal Pradesh in the Indo-Burma biodiversity hotspot, Current Science, 89 (4), 623-634

[20] Mao, A.A., Singh, K.P. and Hajra, P.K.. 2001, Rhododendrons, In: Singh, N.P. and Singh, D.K. eds, Floristic diversity and conservation strategies in India: Volume IV: Angiosperms (Selected Groups), Economic and Ethnobotany, Kolkata, Botanical Survey of India

[21] Singh, K.K., Rai, L.K. and Gurung, B., 2009, Conservation of Rhododendrons in Sikkim Himalaya: An Overview, World Journal of Agricultural Sciences, 5(3), 284-296

[22] Bharali, S. and Khan, M.L., 2011, Climate change and its impact on biodiversity; some management option for mitigation in Arunachal Pradesh, Current Science, 101(7), 855-860

[23] Olson, D.M. and Dinerstein, E., 1998, The global 200: a representation approach to conserving the Earth's most biologically valuable ecoregions, Conservation Biology, 12(3), 502-515

[24] FSI 2009, State of Forest Report, Ministry of Environment and forest, Govt. of India, Dehra Dun

[25] Parihar, A.P.S and Gadagkar, N.P.S., 1986. Geology of the Mechukha area, West Siang District, Arunachal Pradesh, Progress Report for the field season 1985-86, Geological Survey of India, Government of India 
[26] Jain, S.K. and Rao, R.R., 1977, A handbook of field and herbarium technique. Today and Tomorrow Publisher, New Delhi, India

[27] Uma Shankar, 2001, A case study of high tree diversity in a sal (Shorea robusta) dominated lowland forest of Eastern Himalaya: floristic composition, regeneration and conservation, Currernt Science, 81(7), 776-786

[28] Khumbongmayum, A.D., Khan, M.L. and Tripathi, R.S., 2005, Biodiversity conservation in sacred groves of Manipur, northeast India: population structure and regeneration status of woody species, Biodiversity and Conservation, 15(8), $2439-2456$

[29] Jones, R.H., Sharitz, R.R., Dixon, P.M., Segal, D.S. and Schneider, R.L., 1994, Woody plant regeneration in four floodplain forests, Ecological Monographs, 64(3), 345-367

[30] Tesfaye, G., Teketay, D., Fetene, M. and Beck, E., 2010, Regeneration of seven indigenous tree species in a dry Afromontane forest, southern Ethiopia, Flora - Morphology, Distribution, Functional Ecology of Plants, 205(2), 135-143

[31] Paul, A., 2008, "Studies on diversity and regeneration ecology of Rhododendrons in Arunachal Pradesh," Ph.D. thesis, Assam University, Silchar, India

[32] Miyadokoro, T., Nishimura, N. and Yamamoto, S., 2003, Population structure and spatial patterns of major trees in a subalpine old-growth coniferous forest, central Japan, Forest Ecology and Management, 182(1-3), 259-272

[33] Shrestha, B.B., Ghimire, B., Lekhak, H.D. and Jha, P.K., 2007, Regeneration of treeline Birch (Betula utilis D. Don) forest in a trans-Himalayan dry valley in central Nepal, Mountain Research and Development, 27(3), 259-267

[34] Wangda, P. and Ohsawa, M., 2006, Structure and regeneration dynamics of dominant tree species along altitudinal gradient in a dry valley slopes of the Bhutan Himalaya, Forest Ecology and Management, 230(1-3), 136-150

[35] Yang, Y., Yuan, X., Li, B., Sun, R. and Wang, Q., 2007, Characteristics and significance of the remnant evergreen broad-leaved forest in the urban area of Chongqing, China, Biodiversity Science, 15(3), 247-256

[36] Zegeye, H., Teketay, D. and Kelbessa, E., 2011, Diversity and regeneration status of woody species in Tara Gedam and Abebaye forests, northwestern Ethiopia, Journal of Forestry Research, 22(3), 315-328

[37] Teketay, D., 1997, Seedling populations and regeneration of woody species in dry Afromontane forests of Ethiopia, Forest Ecology and Management, 98(2), 149-165

[38] Tesfaye, G., Teketay, D. and Fetene, M., 2002, Regeneration of fourteen tree species in Harenna forest, southeastern Ethiopia, Flora - Morphology, Distribution, Functional Ecology of Plants, 197(6), 461-474

[39] Tesfaye, G., Teketay, D., Fetene, M. and Beck, E., 2010, Regeneration of seven indigenous tree species in a dry Afromontane forest, southern Ethiopia, Flora - Morphology, Distribution, Functional Ecology of Plants, 205(2), 135-143

[40] Rong, Z. and Li-xin, Y.E., 2006, Population structure and distribution pattern of Rhododendron simiarum population in Fengyang Mountain Natural Reservation, Journal of Anhui Agricultural Sciences, 34(22), 5860-5862
[41] Zhang, W.H., Wang, Y.P., Kang, Y.X. and Liu, X.J., 2004, Age structure and time sequence prediction of populations of an endangered plant, Larix potaninii var. chinensis, Biodiversity Science, 12(3), 361-369

[42] Bazzaz, F., 1991, Regeneration of tropical forest: physiological responses of pioneer and secondary species, In: Gomez-Pompa, A., Whitmore, T.C. and Hadley, M. eds, Rain forest regeneration and management, Parthenon Publishing, UNESCO, Paris

[43] Augspurger, C.K., 1984, Pathogen mortality of tropical tree seedling: experimental studies of the effects of dispersal distance, seedling density and light condition, Oecologia, 61(2), 211-217

[44] Klinka, K., Carter, R.E. and Feller, M.C., 1990, Cutting old-growth forests in British Columbia: Ecological considerations for forest regeneration, Northwest Environmental Journal, 6, 221-242

[45] Nilsen, E.T., Walker, J.F., Miller, O.K., Semones, S.W., Lei, T.T. and Clinton, B.D., 1999, Inhibition of seedling survival under Rhododendron maximum (Ericaceae): could allelopathy be a cause, American Journal of Botany, 86(11), $1597-1605$

[46] Nilsen, E.T., Clinton, B.D., Lei, T.T., Miller, O.K., Semones, S.W. and Walker, J.F., 2001, Does Rhododendron maximum L. (Ericaceae) reduce the availability of resources above and below ground for canopy tree seedlings, The American Midland Naturalist Journal, 145(2), 325-343

[47] Peterken, G.F., 2001, Ecological effects of introduced tree species in Britain, Forest Ecology and Management, 141(1-2), 31-42

[48] Lei, T.T., Semones, S.W., Walker, J.F., Clinton, B.D. and Nilsen, E.T., 2002, Effects of Rhododendron maximum thickets on tree seed dispersal, seedling morphology, and survivorship, International Journal of Plant Science, 163(6), 991-1000

[49] Pokhriyal, P., Uniyal, P., Chauhan, D.S. and Todaria, N.P., 2010, Regeneration status of tree species in forest of Phakot and Pathri Rao watersheds in Garhwal Himalaya, Current Science 98(2), 171-175

[50] Tiwari, G.B.G., Pananjay, K., Tadele, K., Aramde, F., and Tiwari, S.C., 2010, Community structure and regeneration potential of Shorea robusta forest in subtropical submontane zone of Garhwal Himalaya, India, Nature and Science, 8(1), $70-74$

[51] Chauhan, D.S., Dhanai, C.S., Singh, B., Chauhan, S., Todaria, N.P. and Khalid, M.A., 2008, Regeneration and tree diversity in natural and planted forests in a Terai-Bhabhar forest in Katarniaghat Wildlife Sanctuary, India, Tropical Ecology 49(1), 53-67

[52] Bruggink, M., 1993, Seed bank, germination and establishment of ericaceous and gramineous species in heathlands, In: Aerts, M.A. and Heil, G.W. eds, Heathlands: Patterns and processes in a changing environment. Kluwer Academic Publication, Dordrecht, Holland

[53] Vera, M.L., 1997, Effects of altitudes and seed size in germination and seedling survival of heathland plants in north Spain, Plant Ecology, 133(1), 101-106

[54] Cho, M.S,, Jung, J.H, and Yeam, D.Y., 1981, Studies on 
seed germination of rhododendron plants, Journal of the Korean Society of Horticultural Science, 22(2), 107-120

[55] Blazich, F.A., Warren, S.L., Acedo, J.R. and Reece, W.M. 1991, Seed germination of Rhododendron catawbiense and Rhododendron maximum: influence of light and temperature, Journal of Environmental Horticulture, 9: 5-8

[56] Blazich, F.A., Warren, S.L., Starrett, M.C. and Acedo, J.R., 1993, Seed germination of Rhododendron carolinianum: influence of light and temperature, Journal of Environmental Horticulture, 11, 55-58

[57] Rowe, D.B., Blazich, F.A., Warren, S.L. and Ranney, T.G., 1994, Seed germination of three provenances of Rhododendron catawbiense: influence of light and temperature, Journal of Environmental Horticulture, 12(3), 155-158

[58] Shrestha, B.B., 2003, Quercus semecarpifolia Sm. in the Himalayan region: Ecology, exploitation and threats, Hima- layan Journal of Science, 1(2) 126-128

[59] Facelli, J.M, and Pickett, S.T.A., 1991, Plant litter - Its dynamics and effects on plant community structure, Botanical Review, 57(1), 1 - 32

[60] Kameyama, Y., Nakagoshi, N. and Nehira, K., 1999, Safe site for seedlings of Rhododendron matternichii var. hondoense, Plant Species Biology, 14(3), 237-242

[61] Bormann, F.H.and Likens, G.E., 1979, Pattern and process in a forested ecosystem. Springer-Verlag, New York

[62] Sundriyal, R.C.and Sharma, E., 1996, Anthropogenic pressure on tree structure and biomass in the temperate forest of Mamlay watershed in Sikkim, Forest Ecology and Management, 81(1), 113-134

[63] Koirala, M., 2004, Vegetation composition and diversity of Piluwa micro-watershed in Tinjure-Milke region, East Nepal, Himalayan Journal of Sciences, 2(3), 29-32 